\title{
EFFECT OF AFFIRMATION FLASHCARDS ON LEVEL OF ANXIETY IN SECOND STAGE OF LABOR AT MIDWIFERY CLINIC, EAST JAVA
}

\author{
Esty Puji Rahayu, Lailatul Khusnul Rizki
}

Universitas Nahdlatul Ulama Surabaya

\begin{abstract}
ABSTRAK
Background: The Indonesia Demographic and Health Survey (IDHS) 2017 reported a high maternal mortality rate (MMR) in Indonesia. Safe and effective management of the second stage of labor presents a clinical challenge for laboring women and practitioners of obstetric care. This study aimed to examine effect of affirmation flashcards on level of anxiety in second stage of labor at midwifery clinic, East Java.

Subjects and Method: This was a quasi-experiment with pre and post-test design was conducted at Mei Kurniawati, Amd.Keb midwifery clinic, Surabaya from July to September 2020. A sample of 30 pregnant women who planned to give birth normally at Mei Kurniawati, Amd.Keb midwifery clinic was selected by simple random sampling. The dependent variable was anxiety in second stage of labor. The independent was flashcard affirmation treatment. The data were analyzed by Paired T test.

Results: Effect of Flashcard Affirmation treatment on anxiety, control variable (Mean=-3.70; $\mathrm{SD}=1.48 ; \mathrm{p}<0.001)$ was higher than treatment variable (Mean= -2.15; $\mathrm{SD}=1.44 ; \mathrm{p}<0.001$ ). Effect of flashcard affirmation on the duration of second stage of labor, control variable was higher $($ Mean $=-8.88 ; \mathrm{SD}=3.81 ; \mathrm{p}<0.001)$ than treatment variable $(\mathrm{Mean}=-1.02 ; \mathrm{SD}=1.17 ; \mathrm{p}<$ 0.001).

Conclusion: Maintaining the mother's psychological condition can be done by giving positive affirmations to the mother, besides that the support of husband and family is also an important point, for that research that may be carried out to develop this research is the role of husband support in the smooth delivery of labor.
\end{abstract}

Keywords: flashcard affirmation, second stage of labor, anxiety

\section{Correspondence:}

Esty Puji Rahayu. Universitas Nahdlatul Ulama Surabaya. Jl. SMEA no.57, Surabaya. Email: esty@unusa.ac.id Mobile: 085755196600. 